\title{
Regular Guys \\ 34 Years Beyond Adolescence
}




\title{
Regular Guys
}

\section{Years Beyond Adolescence}

\author{
DANIEL OFFER \\ Northwestern University \\ Chicago, Illinois \\ MARJORIE KAIZ OFFER \\ Northwestern University \\ Chicago, Illinois \\ and \\ ERIC OSTROV \\ Private Practice \\ Chicago, Illinois
}


Offer, Daniel.

Regular guys : 34 years beyond adolescence / by Daniel Offer, Marjorie Kaiz Offer, and Eric Ostrov.

$$
\text { p. } \mathrm{cm} \text {. }
$$

Includes bibliographical references (p. ) and index.

ISBN 0-306-48585-0

1. Middle aged men-Psychology-Longitudinal studies. I. Offer, Marjorie Kaiz. II.

Ostrov, Eric, 1941- III. Title.

ISBN 0-306-48548-6

(C) 2004 by Kluwer Academic/Plenum Publishers, New York 233 Spring Street, New York, New York 10013

http://www.kluweronline.com

$\begin{array}{llllllllll}10 & 9 & 8 & 7 & 6 & 5 & 4 & 3 & 2 & 1\end{array}$

A C.I.P. record for this book is available from the Library of Congress.

All rights reserved.

No part of this work may be reproduced, stored in a retrieval system, or transmitted in any form or by any means, electronic, mechanical, photocopying, microfilming, recording, or otherwise, without written permission from the Publisher, with the exception of any material supplied specifically for the purpose of being entered and executed on a computer system, for exclusive use by the purchaser of the work.

Permissions for books published in Europe: permissions@wkap.nl Permissions for books published in the United States of America: permissions@wkap.com

Printed in the United States of America 
To Kenneth I. Howard

Happy the man who finds a generous friend

Greek Proverb

To Seymour P. Kaiz, M.D. and Ruth Jacobson Kaiz who always believed it could be done

À mi esposa y todos mis niños con amor hasta siempre 


\section{Acknowledgments}

Completing any scholarly study requires the help of many colleagues, friends, and family. Since the adulthood phase of the Offer Longitudinal Study was primarily self-funded by the senior and second author, supportive expertise was given, for the most part, pro bono. Our gratitude to those who contributed their skills is indescribable. At every step of the project, these persons gave with a generosity that is unmatched in our experience.

We received expert consultation in each phase of this study from the late Kenneth I. Howard, Professor of Psychology, Northwestern University and the Patricia M. Nielsen Research Chair, The Family Institute at Northwestern University. He was with the project from its inception in 1963. The sharing of his time, intellect, and resources during an 11-year period of this study made this entire endeavor possible. We miss him profoundly.

Of great assistance to us was a three-year research grant from Thomas F. Pick of Northfield, Illinois. His investment in our efforts gave us enormous affirmation and allowed us to continue with enhanced confidence. We shall always be grateful for this gift.

We are deeply indebted to the late Judith Baskin Offer and Melvin Sabshin whose contributions to the first two books in this study, The Psychological World of the Teenager and From Teenage to Young Manhood, gave us a bedrock on which to build this scientific undertaking.

We have been greatly helped throughout this research project by people whose special talents made all the difference. We wish to thank Michael Susman of Henry R. Ferris \& Company, who helped locate the most difficult-to-find subjects; and Marge Deitelbaum Jaffe, who contributed to the search for the subjects. We are indebted to Susan Taber, Regina Casper, the late Andrew Boxer, Dan P. McAdams 
and Charles B. Strozier for help in development and the critique of the interview instrument.

We are grateful to Susan Tabor, Janet Shiff, Larry Shiff, Judith Marshal Jobbitt, Thomas Marshall, Mark Epperson, Allan S. Cohen, and George Franklin for participation in the testing of this instrument. We want to give special thanks to Susan Taber who generously traveled the U.S. interviewing many of the subjects. Her contribution was immeasurable and invaluable.

During our travels around the U.S. to interview subjects, we were aided by Pamela Tremayne, Atlanta, Georgia; Sally Allen, the Gary-Williams Energy Corporation, Denver, Colorado; Maria Boyd, the Upland Public Library, Upland, California; Ruth and Allan Schacter, Pittsburgh, Pennsylvania; Susan Frank, Michigan State University, East Lansing, Michigan; Mark A. Wellek of Phoenix, Arizona; Eileen Higgins, the Glen Ellyn Public Library, Glen Ellyn, Illinois; the Northwest Branch of the Tampa Public Library, Tampa Florida; Nancy and Dicran Goulian, New York City; Marsha Slomowitz, Northwestern University Medical School, Chicago, Illinois; Carol Davis and Sandy Hazen, the American Psychiatric Association, Washington, D. C.; and Mary and Morry Joftus, St. Louis, Missouri.

The transcriptions of the interviews could not have been completed without the talents of Lucina Gallagher and Jerry Kayne.

We are indebted to Bruce Brisco for supervising with the data entry and the generation of the frequency counts. In addition, he was responsible for all the computer services for the entire project including the statistical analysis. His understanding of the study and its organization was invaluable. He was always there when we needed him.

We thank Zoran Martinovich of Northwestern University for his aid in the statistical analysis as well as support with the tables and figures. Also providing thoughtful computer support was Al Erlebacher and Josh Mangoubi. Sari Landsman Knight, an intern, provided insight during the first analysis of the subjects in the three routes.

We want to say a special thank you to staff members of Northwestern University who have been so helpful. Sandra Downey has been wonderfully supportive in preparing this manuscript. We owe a debt of gratitude to Elizabeth Crown of University Relations who has helped bring the study to the attention of both the health sciences and general community worldwide.

We have been helped in the writing of this book by three talented colleagues: Cybelle Weisser, whose writing gift has allowed us to tell the compelling story of three subjects in a most interesting way; Emily Bennett, whose contribution to the chapter on the overview of the literature in this book was most helpful; and David Albert, who provided the background for the family constellation literature review.

Throughout the 13 years it took to complete this research project and subsequent book, there were several people who continuously provided support, suggestions, and confidence. First among those are our children Raphael E. Offer, 
Susan Offer Szafir, and Tamar Offer Yehoshua. A special thank you for all those years of listening. Friends also provided wise consul and advice including Sue Pick, Ivan Dee, Barbara Burgess, Marcine Weiner, Arthur Weiner, Margaret Schaffer, Peter Barglow, Jan Smith, Elaine Trikolas Kisisel, Suzanne Grais Hammond, Carol Tavis, and Jane Davis. A special thank you to Gerald H. Kaiz.

And for the 67 men who participated in the middle-age phase of the Offer Longitudinal Study, we feel gratitude, admiration, and affection. Thank you for sharing your lives with us over 34 years. Your willingness to continue to participate in this phase of the story is historically unprecedented. It allowed for a subject follow-up rate (94\%) over a 34-year period that has not been matched in psychiatric or psychological longitudinal research in the $20^{\text {th }}$ century. We salute you, our regular guys. 
There was never yet an uninteresting life.

Such a thing is an impossibility.

Inside the dullest exterior there is a drama, a comedy, and a tragedy.

-Mark (Samuel Clemens) Twain 


\section{Contents}

Chapter 1 Introduction ............................................................ 1

Chapter 2 • The High School Years ............................................. 5

Chapter 3 • The Young Adulthood Years ........................................... 13

Chapter 4 - Tony, Bob, Carl: Adolescence and

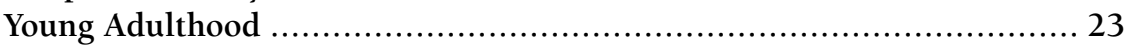

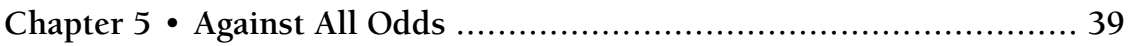

Chapter 6 • Men in Late Middle Age ............................................ 51

Chapter 7 • Tony, Bob, and Carl In Late Adulthood ........................... 71

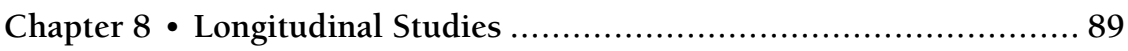

Chapter 9 • Normal Adolescent Boys as Adults ............................... 95

Appendix A: Representations of the Data: Figures 1-69 ...................... 105

Appendix B: Subjects' Offer Self-Image Questionnaire

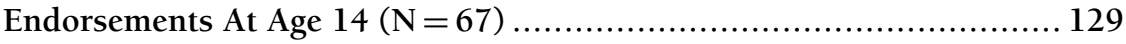

Appendix C: Subjects' Hess, Henry, and Sims Identity Scale

Endorsements at Age $19(\mathrm{~N}=52)$ 141 
Appendix D: Subjects' Symptom Check List 90-Revised

Endorsements at Age $48(\mathrm{~N}=67)$

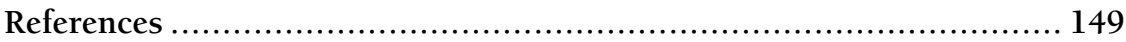

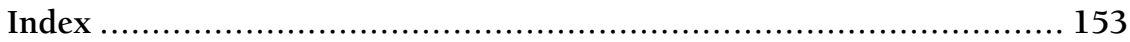

